\title{
Influence of Corporate Social Responsibility on Organizational Citizenship Behavior through Double Mediation Analysis
}

\author{
Farah Khan* \\ Department of Software Engineering, University of Lahore, Lahore
}

\begin{abstract}
Previous literature has examined the direct relationship between the concept of corporate social responsibility \& organizational citizenship behavior. Present study is investigating the mediated link between CSR \& OCB through organizational justice \& organizational identification. Theory of Social exchange \& social identity are supporting our study by providing foundations for interpretation that organizational social responsible behavior can influence OCB of employees through justice and their identification perception. Tests applied to the randomly selected data of 212 employees from different organizations of Pakistan. Our findings show fully mediated relationship between CSR \& OCB through organizational justice and organizational identification. CSR towards employees has a strong relationship with OCB. The findings in this study will help in enhancing role of CSR for employees OCB.

Keyword: Corporate Social Responsibility, organizational citizenship behavior, organizational justice, organizational identification
\end{abstract}

\section{Introduction}

Various studies have observed the direct relationships between Corporate Social Responsibility (CSR) and other organizational outcomes, why dont anyone analyze the process through which this relationship occurs (Farooq et al., 2014). We are conducting a study in which CSR \& Organizational Behavior (OCB) will be examined through mediated mechanism of organizational justice and organizational identification (OI). Previously CSR was analyzed with affective organizational commitment through organizational trust and organizational identification (Farooq et al., 2014). Literature has discussed that CSR can influence organizational citizenship behavior of employees (Gond et al., 2010). Study should focus on the mediation process through which a relationship occurs for better practical implications. If any relationship will be left unaddressed, causalities will be occurred. To address such issues we are going to do investigation on this relationship through mediating role of organizational justice (OJ) and organizational identification with support of theory of social exchange \& social identity in context of Pakistan. Glavas and Godwin (2013) have used social identity theory to test the relationship between CSR \& OI.

The current study proposes that double mediation link between CSR \& OCB can give better understanding about the processes at workplace \& enables management of the organization

*Corresponding author.

Email: farah.khan.cs@uol.edu.pk

http:/ /www.jbrc.pk 
towards initiatives of CSR. Therefore we are going to adopt double mediation method to cultivate a theoretical model of influence of CSR on OCB of employees. Social exchange theory can also support this towards positive link between CSR \& OCB through OJ. If employees will be treated fairly, in return they exert effort towards organizational performance. Impacts and effects of dimensions of CSR were analyzed that how CSR influences employee performance and other outcomes (Turker, 2009). These dimensions of CSR can influence employees towards performance through process of exchange and identification. In our study we will focus on internal CSR dimension i.e. CSR towards employees, to relate it with OCB. It is our concerned dimension over here because employees OCB is the behavior which will be affected internally through organizational justice \& organizational identification. CSR towards employees can influence employees more effectively as compared to other dimensions. After understanding this relationship managers would be able to assist employees to develop OCB through CSR. Once employees will observe that their organization is socially responsible, they would be able to develop sense of give back to their organization.

We are testing our model in one of the developing countries i.e. in Pakistan. On the other hand, we are going to find out the solutions for problems which employees face regarding organizational behavior in Pakistan. Organizations ought to think over that how they treat employees, in return it will motivate employees to perform better role in the organization which will lead towards OCB. In this way employees will want to be identified with such organization which is responsible for the people outside and inside the organization. We are suggesting that how these kinds of problems can be solved through organizations CSR approach. These are the variables which are sensitive areas for a manager to be improved in organization. In our point of view CSR can help an organization to improve such problems through proper management. In this paper we will discuss that what roles organizational justice and organizational identification as intermediaries play in the association between CSR and OCB.

First section of our study will review the concept of CSR. Then next section will discuss impacts of CSR on OCB through OI \& OJ. Social identity theory and social exchange theory will also be discussed to support these links. Then methodology will be developed using preacher

\& Hayes to estimate model. Finally results, managerial implications \& future directions will be discussed.

\section{Literature Review}

\subsection{Corporate social responsibility (CSR)}

Corporate social responsibility has already been discussed by scholars for several managerial disciplines (Hansen et al., 2011). CSR is defined by council for supportable development of world business as:

the ongoing commitment by business to act morally and add to economic development while refining the quality of life of the workforce (Birth et al., 2008).

Various organizations are now taking part in social activities by addressing social concerns which can affect people. This includes employees within the company, supply chain, customers and community in which company survives. CSR towards employee is one of the key points for the social aspects of CSR. We have excluded other dimensions of CSR due to irrelevancy with the current study. 
- CSR Towards employees: Our concerned dimension is CSR towards employee. This is internal CSR that has direct strong relationship with OCB. Employee is the one who takes organization from decline stage to maturity. Why do organizations always expect employees to behave in extra manner to facilitate organizations, organizations should also focus to facilitate them. Organizations should be responsible towards employees benefits beyond formal contracts terms and conditions. Organizations should be responsible for equal distribution of outcomes, for fair treatment, regardless of all types of diversity. When a human being perceives to be treated with care, in exchange he/she will respond in the same way.

Research classifies CSR and workforces in two comprehensive categories. Chief category states that how actions of an organization regarding CSR can effect employees actions (Backhaus et al., 2002). Social identity theory supports this concept that if organizations keep engaging themselves in welfare of its stakeholders, it creates reputable image in the mind of employees. Organizations social responsibility influences employees satisfaction for job positively through programs designed for ethics (Valentine and Fleischman, 2008). Literature examines the link between CSR \& employees engagement and commitment which shows positive results (Farooq et al., 2014). These findings from literature clear us that employees want to be identified with organizations which are linked with society for its development; as an outcome they stay committed to organizations. Literature has focused on the link between CSR \& identification as organizational identification is the part of social identity process (Fischer et al., 2007). Organizational identification was also linked with CSR. Organizational identification is insight of unanimity with or belongingness to an organization, where the individual denes him or herself in terms of the organization(s) in which he or she is a member (Bhattacharya et al., 1995). CSR has positive impact over organizational identification through which members act can be affected positively (Fischer et al., 2007). As a whole literature on CSR demonstrating that there is a straight and solid relationship between CSR \& employees outcomes, we just need to explore other mechanisms which can affect these relationships.

Our study is contributing to the literature in different ways. We have discussed identification aspect of CSR, social exchange process has also been discussed which suggests that if organization is engaged in CSR related activities then this will make perception in the mind of employees that organization cares for them and kind to them \& then employees reciprocate in the same manner with positive attitudes. We suggest that CSR can influence OCB of employees through organizational justice and identification. Organizational justice is defined as a persons perception about organization to be fair in all aspects (Bies and Shapiro, 1988). Organizational justice is about the perception of employees within organization while CSR is about the fairness of organization with external entities as well. So we can say that CSR involves organization in all those activities which are ethical, moral and benefit its employees and other members of the society. It was hypothesized by Zhang et al. (2006) that CSR can influence employees perception about justice and then automatically employees performance can be affected. Overall this study will present another mechanism for the association between CSR and OCB.

\subsection{Organizational citizenship Behavior}

Organizational citizenship behavior is another significant concept to be discussed in the area of management. Organ (1988) presented a huge contribution in the field of management by adding OCB as an important factor for the development of employee performance (Podsakoff et al., 2000). High level of OCB increases productivity level and chances of success. Researchers 
define $\mathrm{OCB}$ as:

A set of voluntary and optional behaviors which are not part of individuals official duties; however, they are carried out and lead to effective improvement of tasks and roles at the organization (Appelbaum et al., 2007). Organ (1988) explained five dimensions of OCB, which can play important role in affecting organizations overall performance.

- First is altruism, it is the behavior that has effect of helping colleagues within organization for organizational tasks.

- Second is conscientiousness, it includes behavior that is beyond basic role requirement of organization (Wong, 2009).

- Third is Civic virtue, it is characterized by behavior in which employees have deep concerns and interests in the organizational development (Jamali and Mirshak, 2007). This is the positive kind of involvement from employees (Weyzig, 2006).

- Fourth is Courtesy, is kind of behavior in which employee tries to avoid has conflicts with others (Hansen et al., 2011). It also states that one should remain polite and wise to others (Nielsen et al., 2012).

- Last is sportsmanship, it has been defined as ability to tolerate undesirable organizational circumstances. Sportsmanship ultimately saves time when employees reduce to complain.

OCB is motivating tool for employees to perform well (Bienstock et al., 2003), it also enhances the satisfaction of employees (Abdullah and Rashid, 2012). There is a strong association between organizational performance and OCB thats why various studies were conducted on the bases of consequences and antecedents of OCB. Literature states that CSR can influence and enhance OCB of employees which is important for development of an organization (Khan et al., 2014). Another aspect of CSR is about legal activities, which is very important for OCB. Employees perception about organizational legal acts can affect OCB (Dutton et al., 1994). Being citizen of a society, an individual perceives all business entities to perform in ethical way and legal ways (Pinkston and Carroll, 1996). In this way good OCB can be enhanced in employees through which they will want to be identified with reputed organizations (Thomas et al., 2004). It is employees perception that if organization is engaged in CSR then it is concerned about well-being of the society, then employees show positive behavior and perform positively which shows strong link between CSR and OCB (Turnipseed and Rassuli, 2005).

\section{Theoretical Framework and Research Model}

We suggest that organizational justice and organizational identification are two effects of CSR which can influence employees OCB. We are conducting a study in which influence of CSR on OCB of employees will be mediated through organizational justice \& organizational identification. We suggest that internal CSR (towards employees) will affect OCB of employees through social exchange and social identity mechanisms. In our paper we are discussing double mediation in which organizational identification is a mediator for employees perceived organization citizenship behavior through organizational justice. If this treatment is in terms of fairness then 
it will show justice which will motivate an individual towards better performance. If employees will be treated properly it will make them feel valued, they would like to be identified with organization which will ultimately enhance OCB as well.

\subsection{Organizational Justice as Mediator: Social Exchange Mechanism}

As literature gives us data about OCB that Organizational citizenship behavior is related to the outcomes which are beneficial for organization such as goal attainment, better productivity \& improved ethical environment (Wright and Sablynski, 2008). Socially responsible behavior of organization can make employees to be more productive towards organization (Hansen et al., 2011). Additionally combine literature of Lindgreen and Swaen (2010) suggests that CSR can enhance positively employees perception of organizational justice. If employees will be treated fairly, in exchange they will perform well. Social exchange theory supports this exchange relationship between organization \& employee. Basically social exchange theory is built on proper exchange process of emotions and resources between supervisor and employees (Blau, 1964). The key opinion of the theory is that individuals carry out their social contact in the very similar way that businesses carry out economic exchange. Another study suggests that the relationship between supervisor \& employee can be influenced positively by fair treatment as well \& it is important to know that how supervisor or management of organization treat employee (Cropanzano and Mitchell, 2005).

To support this notion first we will discuss briefly origin of justice and then literature about it. Organizational justice was firstly generated by Greenberg, which states that an individual perceives organization to be fair in all aspects (Greenberg, 1987). Justice is a decision or action taken by an entity which is morally right. Justice at workplace can be linked to ethics, law, religion etc. according to organizational point of view justice is associated with fairly given pay, promotion with justice, fair selection criteria (Usmani and Jamal, 2013).

We are taking Organizational justice as a whole but for understanding of overall organizational justice we will briefly discuss dimensions of Organizational justice. There are important components of organizational justice which divide overall OJ into three dimensions. First is distributive justice, second procedural justice and last is interactional justice which further includes interpersonal and informational justice (Bies, 1986). Distributive justice is about the justice employees expect from organization in the form of outcomes.

These outcomes can be tangible and intangible in nature such as pay or praise (Adams, 1965). After Adams research about first dimension of organizational justice, two other researchers presented a new measurement of organizational justice as procedural justice (Colquitt, 2001). According to them procedural justice focuses on the procedures used to distribute the outcomes. Interactional justice was presented by Bies (1986), which emphasizes on perception of workers of the interpersonal behavior during decisions and ways (Bies, 1986). It involves social actions such as employees expect to be treated with respect and dignity from supervisor. Further this dimension is divided into two concepts: interpersonal \& informational justice.

When employees perceive that they are treated with respect, dignity and in a polite way while taking decisions then they perceive that the organization deals with interpersonal justice. On the other hand when employees expect timely decisions, truthful information about 
outcomes this will come under informational justice (Colquitt, 2001). Enhanced organizational justice will improve employees performance. Managers should focus on to improve organizational commitment, employees satisfaction and identification with organization to enhance organizational justice through distributive and procedural justice (Usmani and Jamal, 2013).

Corporate social responsibility \& organizational justice give the concept of normative assumption (Rupp et al., 2006). Whenever employees treatment is being discussed, according to CSR norms should be followed for treatment of individual, group and environment. In return employees will respond with responsibility for organization in the form of enhanced OCB. Another research says that attitudes and behaviors of individuals are directly influenced by the treatment they receive from organization in perspective of justice (Cropanzano et al., 2011). We suggest that automatically if organization is socially responsible for employee, will treat them fairly then it will lead towards enhanced OCB.

\section{$H_{1}$ : Employees perception of CSR positively influences employees OCB through perceived OJ.}

\subsection{Organizational Identification as Mediator: Social Identity Mechanism}

Study says that those with high level of organizational identification display better performance at work which promotes their positive response towards organization (Van Knippenberg et al., 2004). Social identity theory proposes that CSR influences positively and directly identification of employees. Individuals seek to maintain positive social identity from different groups (Ashforth and Mael, 1989). Organizational identification is the insight of unanimity with or belonging to an organization among members which is important to the success of many organizations (Mael and Ashforth, 1992). Literature says that employees would like to be identified with the organization which have repute and strong positive image, which will automatically enhance employees self-worth (Turner, 2010). CSR towards employees ensures the support of employees and comfortable environment to work, which will enhance employees perception to be at prestigious place. We therefore propose that CSR to employees can enhance organizational identification.

In terms of social identity, literature suggests that organizational identification has direct link with OCB (Tyler and Blader, 2001). According to Duane, employees perceive that CSR is surely related to OCB (Hansen et al., 2011). Organizational identification \& OCB both are psychological terms which are related to employees outcomes. As literature has given data about the relationship between CSR \& OCB and OI has positive relationship with CSR \& OCB so we suggest that OI can mediate this relationship positively. Therefore, we hypothesized:

\section{$\mathrm{H}_{2}$ : Employees perception of CSR positively influences employees OCB through perceived OI.}

\subsection{Double Mediation between CSR \& OCB through OJ \& OI}

Social identity says that being recognized by reputed organization is a natural and organizational phenomenon which is required by every employee in organization. If employees will be treated fairly and honestly it will naturally influence them to be fair with organization in return. This will enhance their organizational identification automatically. For OCB enhancement organizations ought to be socially responsible for employees to influence their perception 
of identification with organization. When employees are treated fairly they will want to be identified with such organization. They will focus on extra role activities for the better performance (Lipponen et al., 2005). In a study researcher perceived that organizational justice is positively related to organizational identification (Tyler and Blader, 2003). Literature examines the mediation role of organizational identification between organization-focused justice and organization focused outcomes (Lipponen et al., 2005). So previous studies have shown relationship between OJ \& OI, through which we can say that employees want to be identified with such organizations which prevail justice in their systems. In above constructs of organizational justice and organizational identification we have discussed relationship of CSR \& OCB. We suggest that organizational justice can influence organizational identification of employees for our study about CSR \& OCB.

\section{$\mathrm{H}_{3}$ : Employees perception of CSR positively influences employees OI through perception of OJ.}

Employees perceive that socially responsible organization must focus on its employees as well. Our previous hypothesis says that when employees will be treated fairly they will want to be identified with such organization; it will lead to enhanced OCB of employees for organization. Previous discussed all studies and literature says that CSR has strong relationship with other employee related outcomes (Hansen et al., 2011). Relationship of OCB has also been examined with CSR and other organizational variables. Additionally another combined study says that CSR can influence employees perception of OJ \& CSR affects OCB as well (Gond et al., 2010). In that way employees will prefer to work beyond their core responsibilities, which will ultimately improve organizational performance. According to the analysis of the literature we suggest that CSR can enhance OCB of employees when employees will be treated with justice, it will automatically enhance organizational identification of employees which will result in enhanced OCB.

\section{$\mathrm{H}_{4}$ : Employees perception of CSR positively influences OCB through double mediation of OJ $\mathcal{E}$ OI.}

Through different theories we are conducting a study which will result that CSR will influence organizational citizenship behavior of employees through fair treatment and strong identification with organization. Our model has a single path through double mediation. We will finally examine this relationship empirically.

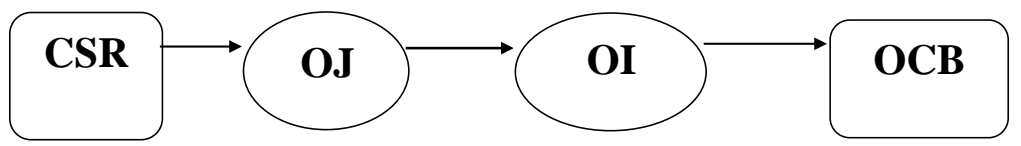

Figure 1: Theoretical Framework 


\section{Research Methodology}

\subsection{Respondents \& Procedure}

In this study, we have surveyed managers and supervisors of four major companies of Lahore, Pakistan. There are a lot of sectors which are growing day by day to facilitate customers in every manner. We have picked those companies for our survey which are involved in CSR activities. Through websites of those companies we got CSR related information, which proves that they are concerned about welfare of the society, those companies are engaged in facilitating customers by providing wide range of healthy and protected products. After market analysis we moved towards data gathering section. We contacted human resource managers of all adopted companies to obtain their help in distributing questionnaires to randomly identified employees. We placed drop box nearby so that employees may put their questionnaires there and anonymity can be maintained (Karriker and Williams, 2009). Respondents were given one week to fill questionnaire and a reminder was given to them through call. We distributed 300 copies of questionnaires and received 230 responses; good response rate was noticed $(70 \%)$ due to face to face and other reminders. After examining missing value final responses were 212 .

\subsection{Instruments}

We have used developed instruments for our study. Variables of the study are well used by previous studies, so there was no difficulty to select instruments from sources. Questionnaire is based on Likert scale ranging from 1-7. In which $1=$ strongly disagree and $7=$ strongly agreed. Before initiating the study we pre tested the questionnaire with few business students to recognize any kind of problem related to items, comprehension and understanding. Pretest revealed no problem regarding duration, content and relevancy.

\subsubsection{Corporate Social Responsibility}

For the measurement of CSR, instruments developed by Turker (2009). Six items were used to measure CSR to employees.

\subsubsection{Organizational Identification}

For Organizational identification six item scale was used the this study administrated all items in a 7-point Likert scale (Mael and Ashforth, 1992).

\subsubsection{Organizational Citizenship Behavior}

For this study 4-item scale on Likert scale was selected to measure OCB developed by Podsakoff et al. (2000).

\subsubsection{Organizational Justice}

For overall measurement of organizational justification instrument using 14-item scale was adopted (Cropanzano and Stein, 2009). 


\section{$5 \quad$ Results and Findings}

In this section we are discussing the examination of data to discover the relationship between independent variable CSR and dependent variable OCB of employees. The mediating role of OJ \& OI is also inspected. Additionally, to check hypothetical relationship between variables, validity of instruments are examined in context of Pakistan. To test our model multiple regressions has been used with the help of SPSS. In our study we have tested descriptive statistics and missing value analysis. Further demographic investigation of respondents was also carried out to know the demographic characteristics of our sample. Data were collected from 300 respondents, out of which 212 respondents filled out the questionnaire in all aspects.

Table 5.1: Missing Value Analysis

\begin{tabular}{ccc}
\hline \multicolumn{3}{c}{ Statistics } \\
\hline \multicolumn{3}{c}{ Missing Value } \\
\hline \multirow{2}{*}{$\mathrm{N}$} & Valid & 212 \\
& Missing & 0 \\
\hline
\end{tabular}

The above table shows that, all cases are now valid, without any missing value. After removing missing values, further tests will be performed.

\subsection{Overall Strategy}

We have evaluated data in overall three steps. First we examined the reliability and validity through CFA (Confirmatory factor analysis) for entire measures (Anderson and Gerbing, 1988).

\subsection{Measurement Validity: CFA}

We have adapted instruments for all variables from well recognized sources still we have to check the reliability and validity in context of Pakistan. For this purpose we have performed CFA for CSR to employees, OJ, OI \& for three dimensions of OCB i.e. loyalty, helping \& industry. We tested a single factor CFA at first in which we aimed to load all items of the six measures on a single factor (Anderson and Gerbing, 1988) and the model fit of a single factor is not good (Table 2). In a single factor $x 2 / d f$ should be less than 5 but in our case it is greater than 5 . The value of GFI, TLI, CFI ought to be greater than 0.90 but in our case it is less. RMSEA ought to be 0.0 but it is greater so model- 1 is not acceptable. We then tested multiple factors analysis in which all items were loaded on their respective factors. In multiple factor analysis $\mathrm{x} 2 / \mathrm{df}$ should be less than 5 and our result is showing less value. The value of GFI, NFI, TLI, and CFI should be greater than 0.90 and RMSEA should be 0.0 , so model-0 is acceptable. The $t$ indices of the multiple factors CFA model were good and within the range of acceptable models (Table 2).

X2 Chi square value, df degree of freedom, GFI goodness-of- $t$ index, NFI normed $t$ index, TLI TuckerLewis index, CFI conrmatory $t$ index, RMSEA root mean square value.

We also examined the convergent and discriminant validity of the instruments. In our case Average variance extracted (AVE) for every instrument was greater than the suggested value of 0.50 , demonstrating satisfactory convergent validity. Discriminant validity was established since the AVE for each construct was greater than any squared correlations (Table 3). 
Table 5.2: Indices of Alternative Models of CFA

\begin{tabular}{lccccccccc}
\hline \multicolumn{7}{c}{ Model } & \multicolumn{7}{c}{ Description of the model } & \multicolumn{7}{c}{ Model Fit Indices } \\
\hline & & X2 & Df & X2/df & GFI & NFI & TLI & CFI \\
\hline MODEL 1 & Single factor CFA & 3995.450 & 435 & 9.185 & 0.370 & 0.280 & 0.251 & 0.299 \\
MODEL-0 & Multiple factor CFA & 480.544 & 335 & 1.434 & 0.861 & 0.906 & 0.965 & 0.969 \\
\hline
\end{tabular}

Table 5.3: Test of Discriminant Validity

\begin{tabular}{|c|c|c|c|c|c|c|c|}
\hline & AVE & ndustry & org-justice & org_identification & helping & loyalty & CSR_Emp \\
\hline Industry & 0.664 & 0.815 & & & & & \\
\hline org-justice & 0.565 & 0.175 & 0.752 & & & & \\
\hline org_identification & 0.795 & 0.213 & 0.433 & 0.892 & & & \\
\hline Helping & 0.819 & 0.071 & 0.382 & 0.263 & 0.905 & & \\
\hline Loyalty & 0.661 & 0.396 & 0.223 & 0.287 & 0.176 & 0.813 & \\
\hline CSR_Emp & 0.792 & 0.052 & 0.270 & 0.270 & 0.136 & -0.026 & 0.890 \\
\hline
\end{tabular}

In the table values given in font which looks bold signify the AVE; other values are the squared correlations among the variables.

\subsection{Reliability of Measuring Instruments}

Table 5.4: Reliability of the Items

\begin{tabular}{lcc}
\hline Scales & Cronbach's Alpha & No of items \\
\hline CSR-Employees & .855 & 6 \\
Organizational Justice & .683 & 6 \\
Organizational Identification & .874 & 5 \\
OCB & .923 & 5 \\
\hline
\end{tabular}

Being reliable is all about being consistent of a measuring instrument. Internal consistency was tested with Cronbachs alpha coefficient for 4 instruments in our study (Ruekert, 1992).

Above table is showing that all of the scales have values of alpha in range from .683 to .923. In social sciences researchers accept value of alpha higher than 0.6 , as values greater than 0.7 is considered as good, above 0.8 is considered as very good, and above 0.9 is considered as excellent. We can see that our all measuring instrument have values of alpha greater than 0.6 which means they have good reliability in context of Pakistan. 


\subsection{Common Method Variance}

We have used common method variance multiple methods such as Harmon one factor, common latent factor to test the common method bias (Podsakoff et al., 2000). The overall analysis of all the variables produced six distinct factors, which together given sum of $81.717 \%$ total variance; where first factor did not sum up majority of the variance (only 37.180\%). Correspondingly, the common method latent factor for mediating, independent, and dependent variables generated only $23.031 \%$ of the common factor, signicantly less than the acceptable Threshold of $25 \%$ podsakoff 2000 . Thus, CMB was not a serious threat for our data.

\section{Results}

\subsection{Descriptive Statistics}

In Table 5 we have provided all required means, standard deviations, and correlations between the model variables. Given correlation table will offer to have a look into all hypothesized and non-hypothesized relationships among the concepts.

Table 6.1: Descriptive Statistics

\begin{tabular}{lccccccccccc}
\hline & Mean Std. Deviation & $\mathbf{1}$ & $\mathbf{2}$ & $\mathbf{3}$ & $\mathbf{4}$ & $\mathbf{5}$ & $\mathbf{6}$ & $\mathbf{7}$ & $\mathbf{8}$ & $\mathbf{9}$ \\
\hline Gender1 & 1.31 & .466 & 1 & & & & & & & & \\
Age1 & 1.56 & .709 & $-.178^{* *}$ & 1 & & & & & & & \\
Education & 2.46 & .570 & $.163^{*}$ & -.079 & 1 & & & & & & \\
HRAVG & 5.17 & 1.39 & -.001 & .097 & -.025 & 1 & & & & \\
OIAVG & 5.70 & 1.18 & .025 & .116 & -.108 & $.256^{* *}$ & 1 & & & & \\
AVGHELP & 4.69 & 1.70 & $-.152^{*}$ & .051 & $-.184^{* *}$ & .126 & $.257^{* *}$ & 1 & & & \\
AVGLOYAL & 4.79 & 1.25 & $-.162^{*}$ & .080 & -.044 & -.016 & $.258^{* *}$ & $.162^{*}$ & 1 & & \\
AVGINDUSTRY & 4.67 & 1.11 & -.050 & .035 & .054 & .052 & $.206^{* *}$ & .062 & $.387^{* *}$ & 1 & \\
AVJOJ & 5.46 & 1.08 & $-.202^{* *}$ & $.210^{* *}$ & -.116 & $.247^{* *}$ & $.438^{* *}$ & $.392^{* *}$ & $.273^{* *}$ & $.153^{*}$ & 1 \\
\hline
\end{tabular}

**. Correlation is significant at the 0.01 level (2-tailed).

*. Correlation is significant at the 0.05 level (2-tailed).

\section{Model Testing}

The hypothesized model produces good fit with the data $(\mathrm{x} 2=584.26, \mathrm{df}=340, \mathrm{v} 2 / \mathrm{df}=$ $1.542, \mathrm{GFI}=0.859, \mathrm{NFI}=0.898, \mathrm{CFI}=0.961$ ). Values are in favor of our model as shown in table 6 below.

\subsection{Mediation Effects}

Notion of mediation infers a causal hypothesis where an independent variable causes a dependent variable, through its effect on a mediating variable (Sobel, 1990). There are specific 
Table 7.1: Fitness of Model

\begin{tabular}{cccccccc}
\hline \multicolumn{10}{c}{ Model } & Description of the model & Model Fit Indices \\
\hline & X2 & Df & X2/df & GFI & NFI & TLI & CFI \\
Hypothesized model & 524.26 & 340 & 1.542 & .859 & 0.898 & 0.957 & 0.961 \\
\hline
\end{tabular}

effects which are of notice in multiple mediation methods (MacKinnon et al., 2000). In (table 7) we provide the direct effects of CSR to employees on OI, OJ \& OCB as well as indirect effects of CSR to employees OCB through mediation of OI \& OJ. CSR to employees has positive influence on organizational identification and organizational justice. CSR to employees has negative effects on loyalty and industry. There is a strong positive effect of mediators on OCB. All indirect effects are significant as shown in table. In our case, the effect of the CSR components on AOC is carried through two parallel mediating paths (via trust and identification). CSR to employees has stronger mediation with helping component of OCB as compared to other components of OCB.

Table 7.2: Direct and Indirect Effects

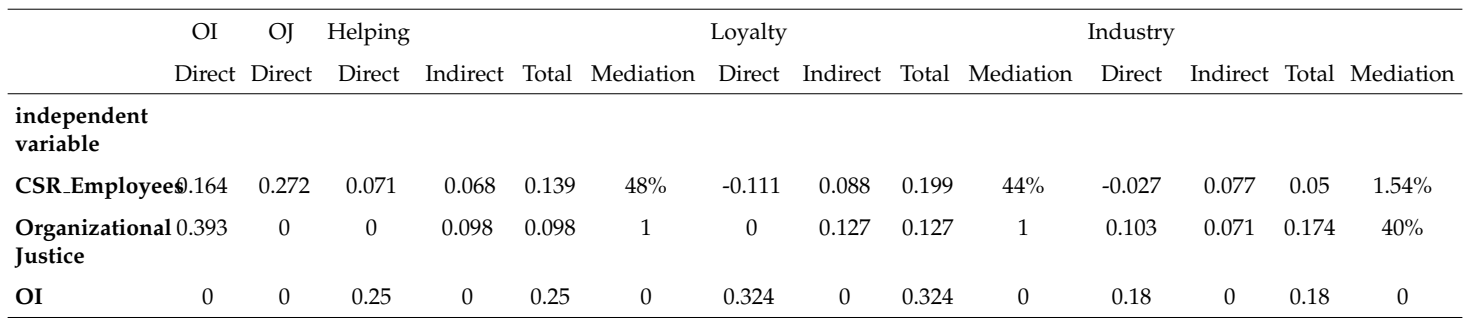

\section{Discussion}

Basic purpose of the current study is to examine the relationship between CSR and OCB through mediation of organizational justice and organizational identification. Using SRM we determined that OCB is one of the strong outcomes of CSR through different mediations. Therefore we can say that OCB is not a direct outcome in fact there are different mechanisms through which this relationship builds.

There is positive contribution of OCB towards literature regarding organizational performance (Bienstock et al., 2003). Previous research has contributed in terms of dimensions and other variables affected by OCB, we have conducted a research in which CSR influenced OCB positively through double mediation. Previously may be this relationship was analyzed for multiple mediation, we have analyzed double mediation between these variables. This finding can give new shape to the mechanisms between CSR \& OCB. Hence this study has contributed to the growing body of research in CSR and organizational outcomes empirically. Previous research says that CSR was analyzed from both perspectives, internal \& external but we have taken internal CSR for our study to analyze the OCB of employees. The results of this study present few 
observable differences concerning CSR, OCB, and OJ \& OI. Thus this study can be presented to organizations as guideline to follow for the help in CSR \& OCB related areas.

\subsection{Managerial Implications}

Previously CSR was discussed in literature as external function for public relation \& development, it can be powerful tool for internal customer as well i.e. employees. Our model suggests that if organizations create a distinctive \& strong corporate image for external audience, they should also focus on to enhance employee performance through CSR. Justice and identification affect job related attitudes like motivation, engagement \& satisfaction (Saks, 2006). Our study has shown useful results for making strategic CSR policies concerning employees. Employees perception about OCB \& overall outcomes can be influenced through CSR. When company gets involve in CSR, employees feel proud to be part of such company. Managers should focus on CSR activities specially related to employees to develop positive behaviors of employees \& to reduce negative behaviors. Organizations mostly ignore the original purpose of CSR \& exhibit CSR only for advertisements and to show off. This study has given a guideline to mangers that this matter should be considered properly for organizational performance. This research has further proved that CSR towards employees can influence strongly the OCB of employees, which will ultimately improve employees overall performance.

\subsection{Future Directions \& limitations}

This study has used data of 212 employees; large sample size can be used to analyze the results across organization. This study also opens up ideas for other studies undertaking other variable to examine for different results. We have used social identity \& social exchange mechanisms, other mechanisms can also be used to analyze same relationship. Future studies can analyze dimensions of organizational justice, dimensions of OCB. This study has used organizational justice and organizational identification as mediator between CSR \& OCB, future research can fill this gap of mediators with other variables. CSR toward OCB have been discussed previously by few researchers, in future new researches should be based on other organizational outcomes. Moreover present research was done in context of Pakistan; new studies can examine these relationships in different context.

\section{References}

Abdullah, M. H. and Rashid, N. (2012). The implementation of corporate social responsibility (csr) programs and its impact on employee organizational citizenship behavior. International Journal of Business and Commerce, 2(1):67-75.

Adams, J. S. (1965). Inequity in social exchange. In Advances in experimental social psychology, volume 2, pages 267-299. Elsevier.

Anderson, J. C. and Gerbing, D. W. (1988). Structural equation modeling in practice: A review and recommended two-step approach. Psychological bulletin, 103(3):411.
Appelbaum, S. H., Iaconi, G. D., and Matousek, A. (2007). Positive and negative deviant workplace behaviors: causes, impacts, and solutions. Corporate Governance: The international journal of business in society, 7(5):586-598.

Ashforth, B. E. and Mael, F. (1989). Social identity theory and the organization. Academy of management review, 14(1):20-39.

Backhaus, K. B., Stone, B. A., and Heiner, K. (2002). Exploringthe relationship between corporate social performance and employer attractiveness. Business E Society, 41(3):292-318.

Bhattacharya, C. B., Rao, H., and Glynn, M. A. 
(1995). Understanding the bond of identification: An investigation of its correlates among art museum members. Journal of marketing, 59(4):4657.

Bienstock, C. C., DeMoranville, C. W., and Smith, R. K. (2003). Organizational citizenship behavior and service quality. journal of services marketing, 17(4):357-378.

Bies, R. J. (1986). Interactional justice: Communication criteria of fairness. Research on negotiation in organizations, 1:43-55.

Bies, R. J. and Shapiro, D. L. (1988). Voice and justification: Their influence on procedural fairness judgments. Academy of management journal, 31(3):676-685.

Birth, G., Illia, L., Lurati, F., and Zamparini, A. (2008). Communicating csr: practices among switzerland's top 300 companies. Corporate Communications: An International Journal, 13(2):182196.

Blau, P. M. (1964). Exchange and power in social life. new brunswick.

Colquitt, J. A. (2001). On the dimensionality of organizational justice: A construct validation of a measure. Journal of applied psychology, 86(3):386.

Cropanzano, R. and Mitchell, M. S. (2005). Social exchange theory: An interdisciplinary review. Journal of management, 31(6):874-900.

Cropanzano, R. and Stein, J. H. (2009). Organizational justice and behavioral ethics: Promises and prospects. Business Ethics Quarterly, 19(2):193-233.

Cropanzano, R., Stein, J. H., and Nadisic, T. (2011). Social justice and the experience of emotion. Routledge.

Dutton, J. E., Dukerich, J. M., and Harquail, C. V. (1994). Organizational images and member identification. Administrative science quarterly, pages 239-263.

Farooq, O., Payaud, M., Merunka, D., and ValetteFlorence, P. (2014). The impact of corporate social responsibility on organizational commitment: Exploring multiple mediation mechanisms. Journal of Business Ethics, 125(4):563-580.
Fischer, C., Jonckx, B., Mazzone, M., Zacchigna, S., Loges, S., Pattarini, L., Chorianopoulos, E., Liesenborghs, L., Koch, M., De Mol, M., et al. (2007). Anti-plgf inhibits growth of vegf (r)-inhibitor-resistant tumors without affecting healthy vessels. Cell, 131(3):463-475.

Glavas, A. and Godwin, L. N. (2013). Is the perception of goodness good enough? exploring the relationship between perceived corporate social responsibility and employee organizational identification. Journal of business ethics, 114(1):1527.

Gond, J.-P., El-Akremi, A., Igalens, J., and Swaen, V. (2010). Corporate social responsibility influence on employees. International Center for Corporate Social Responsibility, 54.

Greenberg, J. (1987). A taxonomy of organizational justice theories. Academy of Management review, 12(1):9-22.

Hansen, S. D., Dunford, B. B., Boss, A. D., Boss, R. W., and Angermeier, I. (2011). Corporate social responsibility and the benefits of employee trust: A cross-disciplinary perspective. Journal of Business Ethics, 102(1):29-45.

Jamali, D. and Mirshak, R. (2007). Corporate social responsibility (csr): Theory and practice in a developing country context. Journal of business ethics, 72(3):243-262.

Karriker, J. H. and Williams, M. L. (2009). Organizational justice and organizational citizenship behavior: A mediated multifoci model. Journal of management, 35(1):112-135.

Khan, H. A., Zahoor, A., and Irum, S. (2014). Impacts of corporate social responsibility on employees behavior in telecom sector of pakistan. European Journal of Business and Management, 6(11):34-43.

Lindgreen, A. and Swaen, V. (2010). Corporate social responsibility. International Journal of Management Reviews, 12(1):1-7.

Lipponen, J., Helkama, K., Olkkonen, M.-E., and Juslin, M. (2005). Predicting the different profiles of organizational identification: A case of shipyard subcontractors. Journal of Occupational and Organizational Psychology, 78(1):97-112. 
MacKinnon, D. P., Krull, J. L., and Lockwood, C. M. (2000). Equivalence of the mediation, confounding and suppression effect. Prevention science, 1(4):173-181.

Mael, F. and Ashforth, B. E. (1992). Alumni and their alma mater: A partial test of the reformulated model of organizational identification. Journal of organizational Behavior, 13(2):103-123.

Nielsen, T. M., Bachrach, D. G., Sundstrom, E., and Halfhill, T. R. (2012). Utility of ocb: Organizational citizenship behavior and group performance in a resource allocation framework. Journal of Management, 38(2):668-694.

Organ, D. W. (1988). Organizational citizenship behavior: The good soldier syndrome. Lexington Books/DC Heath and Com.

Pinkston, T. S. and Carroll, A. B. (1996). A retrospective examination of csr orientations: have they changed? Journal of Business Ethics, 15(2):199-206.

Podsakoff, P. M., MacKenzie, S. B., Paine, J. B., and Bachrach, D. G. (2000). Organizational citizenship behaviors: A critical review of the theoretical and empirical literature and suggestions for future research. Journal of management, 26(3):513563.

Ruekert, R. W. (1992). Developing a market orientation: an organizational strategy perspective. International journal of research in marketing, 9(3):225-245.

Rupp, D. E., Ganapathi, J., Aguilera, R. V., and Williams, C. A. (2006). Employee reactions to corporate social responsibility: An organizational justice framework. Journal of Organizational Behavior: The International Journal of Industrial, Occupational and Organizational Psychology and Behavior, 27(4):537-543.

Sobel, M. E. (1990). Effect analysis and causation in linear structural equation models. Psychometrika, 55(3):495-515.

Thomas, C. D., Cameron, A., Green, R. E., Bakkenes, M., Beaumont, L. J., Collingham, Y. C., Erasmus, B. F., De Siqueira, M. F., Grainger, A., Hannah, L., et al. (2004). Extinction risk from climate change. Nature, 427(6970):145.
Turker, D. (2009). Measuring corporate social responsibility: A scale development study. Journal of business ethics, 85(4):411-427.

Turner, J. C. (2010). Social categorization and the self-concept: A social cognitive theory of group behavior.

Turnipseed, D. L. and Rassuli, A. (2005). Performance perceptions of organizational citizenship behaviours at work: A bi-level study among managers and employees. British Journal of Management, 16(3):231-244.

Tyler, T. R. and Blader, S. L. (2001). Identity and cooperative behavior in groups. Group Processes $\mathcal{E}$ Intergroup Relations, 4(3):207-226.

Tyler, T. R. and Blader, S. L. (2003). The group engagement model: Procedural justice, social identity, and cooperative behavior. Personality and social psychology review, 7(4):349-361.

Usmani, S. and Jamal, S. (2013). Impact of distributive justice, procedural justice, interactional justice, temporal justice, spatial justice on job satisfaction of banking employees. Review of integrative business and economics research, 2(1):351.

Valentine, S. and Fleischman, G. (2008). Ethics programs, perceived corporate social responsibility and job satisfaction. Journal of business ethics, 77(2):159-172.

Van Knippenberg, D., De Dreu, C. K., and Homan, A. C. (2004). Work group diversity and group performance: an integrative model and research agenda. Journal of applied psychology, 89(6):1008.

Weyzig, F. (2006). Local and global dimensions of corporate social responsibility in mexico. Journal of Corporate Citizenship, (24):69-81.

Wong, L. (2009). Corporate social responsibility in china: Between the market and the search for a sustainable growth development. Asian Business $\mathcal{E}$ Management, 8(2):129-148.

Wright, C. W. and Sablynski, C. J. (2008). Procedural justice, mood, and prosocial personality influence on organizational citizenship behavior. North American Journal of Psychology, 10(2). 
Zhang, J., Grindley, J. C., Yin, T., Jayasinghe, S., He, X. C., Ross, J. T., Haug, J. S., Rupp, D., PorterWestpfahl, K. S., Wiedemann, L. M., et al. (2006).
Pten maintains haematopoietic stem cells and acts in lineage choice and leukaemia prevention. Nature, 441(7092):518. 